\title{
Towards a sustainable development licence to operate for the extractive sector
}

\author{
Antonio Pedro ${ }^{1}$ (D) Elias T. Ayuk ${ }^{2}$ - Christina Bodouroglou ${ }^{3}$ • Ben Milligan ${ }^{4}$. \\ Paul Ekins ${ }^{4}$ Bruno Oberle ${ }^{5}$
}

Received: 25 April 2017 / Accepted: 27 April 2017 /Published online: 18 May 2017

(C) The Author(s) 2017. This article is published with open access at Springerlink.com

\begin{abstract}
The extractive sector now holds an even more predominant position for national economies following the adoption of the Sustainable Development Goals in 2015. The sector can make significant contributions to the achievement of a large number of these Goals. Managing extractive resources has always presented a major challenge for many countries worldwide, but especially in the developing world. This paper documents the shortcomings of the existing governance architecture. It builds on the 'social licence to operate' and draws from its limitations to propose a new framework called the 'sustainable development licence to operate'. The latter is a holistic multilevel and multi-stakeholder governance framework aimed at enhancing the contribution of the mining sector to sustainable development. It is not intended to function as a licence in the regulatory sense. The underlying principles, policy options and best practices that form the basis of the proposed framework are outlined in the paper. This analysis should be viewed as a starting point, in recognition that the development of a robust sustainable development licence to operate depends on an open and inclusive approach to populating its normative content.
\end{abstract}

The original version of this article was revised due to a retrospective Open Access order.

Antonio Pedro

pedro.uneca@un.org

1 United Nations Economic Commission for Africa, Yaoundé, Cameroon

2 United Nations University Institute for Natural Resources in Africa, Accra, Ghana

3 United Nations Environment, Paris, France

4 University College of London Institute for Sustainable Resources, London, UK

5 École Polytechnique Fédérale de Lausanne, Lausanne, Switzerland
Keywords Extractive sector · Mining · Governance · Resource curse · Sustainable development goals · Social licence to operate S Sustainable development licence to operate

\section{Introduction}

Mineral wealth, if managed prudently, presents enormous opportunities for advancing sustainable development, particularly in low-income countries. The extractive sector has been identified as an important contributor to the achievement of all 17 Sustainable Development Goals (SDGs) adopted by UN Member States in 2015. ${ }^{1}$ Mining can impact most directly the Global Goals relating to poverty eradication, decent work and economic growth, clean water and sanitation, life on land, sustainable and affordable energy, climate action, industry and infrastructure, as well as peace and justice (UNSDSN 2015).

Recent data published by the International Council of Mining and Minerals (ICMM) clearly shows the potential role of mining in national economies (ICMM 2016). For the poorest countries in the world, the sector can be a driver for economic growth and improved welfare of its people. The 2016 mining contribution index, which ranks 183 countries in the world according to the mining sector's contribution to

\footnotetext{
${ }^{1}$ On 25 September 2015, the 193 member states of the United Nations (UN) adopted a new Agenda for Sustainable Development. The Agenda features 17 Sustainable Development Goals (SDGs) and 169 Targets, which UN Member States have committed to implement by 2030. The 2030 Agenda succeeds the UN Millennium Development Goals (MDGs), which included commitments to achieve by 2015 outcomes focusing on extreme poverty and hunger, primary education, gender quality and empowerment of women, child mortality, maternal health, diseases, environmental sustainability and global partnerships. The 2030 Agenda differs from the MDGs in several key respects-it applies to all countries, recognises a wider range of economic, social and environmental objectives, and defines specific means of implementation. Progress towards the Agenda's 17 Goals and 169 Targets will be assessed using a suite of indicators, agreed in preliminary form in March 2016.
} 
the domestic economy, shows that six of the top ten countries are in Africa. ${ }^{2}$ In addition to generating vast sums of government revenues, extractive projects can also generate benefits by creating employment, fostering demand for domestic goods and services, transferring technologies and know-how, and building infrastructure.

Notwithstanding, mineral-rich nations are confronted with serious challenges in attempting to translate natural resource wealth into long-term inclusive and sustainable development. The phenomenon of resource-rich countries being unable to transform their mineral resource endowments into enhanced growth and well-being for their citizens has received considerable attention in the literature, referred to as the 'resource curse' or 'the paradox of plenty'.

It has long been recognised that governance is key for mitigating the adverse impacts of mining and for enhancing its positive economic, social and environmental outcomes. Nevertheless, most existing policy frameworks and instruments for governing the mining sector tend to present piecemeal efforts and, importantly, often fail to be implemented at the national level. This means that new governance approaches and instruments have not succeeded in bringing about a transition away from the 'extractivist' and anthropocentric model widely prevalent in the developing world, whereby the extractive sector is an enclave with few linkages to the local economy (Acosta 2013). ${ }^{4}$ To achieve this, there would be a need to adopt sustainable development approaches based on new metrics where success is measured on the strength of economic outcomes, sound environmental management, the respect of social values and aspirations and the observance of the highest governance and transparency standards. This more holistic approach is at the core of the Africa Mining Vision (AMV) adopted in February 2009, which argues that mineral resources can catapult Africa to broad-based development and structural transformation (African Union 2009).

Insofar as these issues are currently taken into account in the governance of resource extraction, it is largely through the so-called Social Licence to Operate ${ }^{5}$ (SLO). However, in response to the new imperatives set by the 2030 Agenda for

\footnotetext{
2 The Democratic Republic of Congo comes first with a score of 96.2, followed by Mauritania (95.6), Burkina Faso (94.0), Madagascar (91.7) and Botswana (90.7), and Liberia with an index of 89.0 is at the eighth position (ICMM 2016).

${ }^{3}$ Some of the main arguments explaining this paradox are summarised, for instance, in Stevens et al. (2015).

4 'Extractivism' is defined as 'those activities which remove large quantities of natural resources that are not processed (or processed only to a limited degree), especially for export' (Acosta 2013, p. 62). A legacy that remains since colonial times, the extractivist mode of accumulation refers to the exploitation of raw materials needed primarily to fuel the development and growth of industrialised and emerging nations. It typically generates few benefits for the host country due to the resulting limited demand for domestic labour, goods and services; lack of value addition and linkages to the rest of the economy; depletion of finite resources; environmental destruction; and incentives for 'rent-seeking' behaviour which undermine effective and democratic governance (Ibid).
}

Sustainable Development and the inadequacies of the current paradigm, this paper calls for the SLO to be developed into a new multi-level, holistic and integrated governance framework, applicable to governments, companies and the range of stakeholders involved in the mining sector, which is here referred to as the 'Sustainable Development Licence to Operate' (SDLO) ${ }^{6}$ and which is designed to function as a normative reference point for the multiple actors concerned with the extractive sector, and support their efforts to work together in a manner compatible with the SDGs.

This paper firstly briefly describes the SLO and some of the criticisms that have been made of it (Section 2), followed by the changes in the international context and emerging challenges that have rendered the SLO somewhat outdated (Section 3). After examining the nature of the current governance architecture in the extractive sector, the paper then sets out the key principles and policies that underlie the proposed SDLO (Section 4), together with some of the implications for the reform of resource governance to which they give rise, followed by some concluding remarks (Section 5).

\section{The social licence to operate}

Since the late 1990s, mining companies have increasingly sought to secure the acceptance of mining activities by local communities and stakeholders, build public trust and prevent social conflict (Prno 2013). Such attempts to earn a SLO are premised on engagement between mining companies, governments and civil society to ensure that mineral resource extraction contributes to national and local development, and that damaging impacts on host communities and the environment are mitigated or otherwise managed.

The social licence to operate can be credited with drawing attention to the need for mining companies to bear responsibility for the negative social implications of their practices and to engage in an inclusive and meaningful way with stakeholders. Companies are expected to respond to concerns and requests by affected communities (including indigenous peoples) and broader civil society, provide timely and understandable information, deliver on their commitments, and operate in an honest and responsible manner, and be accountable. While the abstract

\footnotetext{
5 The concept of 'Social Licence to Operate' relates to the broad, on-going acceptance within local communities, and society more broadly, of mining projects. It can be regarded as a largely intangible agreement between mining companies and civil society, based on a growing common understanding of the need for greater public participation in decision-making, a fairer share of mining proceeds, and assurances that mineral development will be conducted safely and responsibly (see, for instance, Prno 2013). Joyce and Thomson (2000) consider that the social licence to operate is a metaphor to depict values, activities and best practices that companies must commit to within society to ensure that their operations are successful.

${ }^{6}$ The term 'Sustainable Development Licence to Operate' was first introduced by Pedro (2015).
} 
nature of this 'social contract' does not imply granting a licence in the legal sense, in some countries social acceptability is a requirement for mining contracts to be issued.

Despite the term's widespread uptake by industry and the aforesaid welcoming attributes, the notion of a social licence to operate can be criticised on a number of grounds. These relate to both the social licence discourse and its practical application (see, for instance, Owen and Kemp 2013; Business Council of British Columbia 2015).

Firstly, the use of the term 'licence' has been seen as misleading, insofar as it is suggestive of the granting of specific permission for or public acceptance of a mining project, even if the reality is one of reluctant tolerance or absence of overt opposition or conflict (Business Council of British Columbia 2015). This can be particularly problematic in certain political contexts where the public expression of dissent may be explicitly prohibited or otherwise punishable.

Moreover, the use of the term 'social' may serve to aggregate diverging opinions among a diverse or heterogeneous group of stakeholders, therefore masking some dissenting or marginalised views (Agrawal and Gibson 1999; Owen and Kemp 2013; Lesser et al. 2017). Importantly, the social licence to operate, as its name suggests, focuses mainly on the social dimension of mining projects, with less attention paid to the environmental component. While some environmental concerns may be addressed if raised by local communities and other actors, the social licence to operate is far from a comprehensive means for protecting the environment from the destructive and polluting impacts of mining. This is linked to a fundamental critique of the social licence framework emphasised by Owen and Kemp (2013), which is that it was developed as industry's pragmatic response to business risk. Its agenda is limited to accommodating community demands to the minimum extent necessary to avoid public opposition and social conflict, and the associated costs of reputational damage and operational delays or disruptions. Its narrow and business-driven agenda means that the social licence to operate is a deficient framework - both in theory and practice - for establishing higher standards of social and environmental performance, and stakeholder engagement for long-term sustainable development. In the absence of explicit conditions for obtaining the licence, of recognition of reciprocal rights and of even access to information, the authors argue that the 'social licence itself is not only unworkable, but its usage by industry can result in perverse development outcomes' and even run 'counter to a sustainable development agenda' (ibid, p. 31; p. 33). They concluded that 'nothing short of a move away from social licence at the project level is required to pave the way for a more proactive stance towards sustainable development' (ibid p. 34).

\section{Imperatives for a new paradigm}

The imperative for a new governance framework arises from the inadequacy of the existing governance landscape, particularly in light of recent developments in the global development agenda, namely the adoption in 2015 of the 2030 Agenda for Sustainable Development. The notion of sustainable development - integrating the three pillars of economic development, social inclusion and environmental sustainability - has become the organising framework for global cooperation and development and is key in framing the discussion.

There is a growing recognition that if well managed, the mining sector can play a positive role in promoting broad-based development and structural transformation in relevant countries. While mining impacts all 17 SDGs to varying degrees, the industry can contribute more directly to the following eight Goals $(1,6$, 7, 8, 9, 13, 15 and 16) (UNSDSN 2015).

Mining generates significant revenues through taxes, royalties and dividends for governments to invest in economic and social development (Goal 1). Mining can help drive economic development and diversification through direct and indirect economic benefits, the development of new technologies and by spurring the construction of new infrastructure for transport, communications, water and energy (Goal 9). It can alter the lives of local communities, offering opportunities for jobs and training, while contributing to economic and social inequities if not appropriately managed (Goal 8). Moreover, mining requires access to land and water, presenting significant and broad landscape impacts that must be responsibly managed (Goals 6 and 15). Mining activities are also energy and emissions intensive in both the production and downstream uses of mining products (Goals 7 and 13). Finally, mining can contribute to peaceful societies by avoiding and remedying company-community conflict, respecting human rights and rights of indigenous peoples, and by supporting the representative decision-making of citizens and communities in extractives development (Goal 16) (ibid).

Despite the potential of the mining sector to act as a catalyst for growth and development in mineral-rich developing countries, there are a number of barriers and challenges that may prevent this potential from being realised. The challenges include the unevenly distributed and finite nature of mineral deposits; the volatility of commodity prices which have exposed developing countries to external shocks triggering macro-economic instability; the difficulties of managing large and volatile inflows of foreign capital, technical complexities of large scale projects and limited national capacities; the enclave nature of the industry with weak linkages to other economic sectors; redefinitions of resource nationalism and the contours of the social licence to operate, with no clear consensus on what would thus constitute shared value from mining (CCSI 2016; EY 2015; PWC 2015); lack of accountability, transparency and risk of corruption; global asymmetries of power; conflicting stakeholder interests leading to social conflict; and lasting environmental damage.

Moreover, it has been argued that technological advances in the extractive sector could have disruptive impacts on job 
creation, local procurement of goods and services as well as change production and supply dynamics with profound geopolitical implications (WEF 2016).

In addition, an important issue in several countries is the discrepancy between formally recognised rights to extractive resources, and the resource-related expectations and dependencies of local communities (Toulmin and Quan 2000). Many local communities around the world are highly dependent on resources (e.g. forests, fisheries, agricultural land) over which they do not enjoy formal property rights (Palmer et al. 2012; RRI 2016; Suárez et al. 2009). Economic development policies in several low- and middle-income countries have in some cases facilitated the large-scale acquisition of formal property rights by commercial sector actors, in particular to enable mining and plantation agriculture (Cotula et al. 2014, 2009). These acquisitions are often characterised by the involvement of TNCs which are difficult to regulate for various reasons. Negative outcomes associated with large-scale property acquisition by the extractive sector in low- and middle-income countries include expropriation without adequate compensation of formal rights held by individuals and communities, extinguishment of long-standing informal rights held by individuals and communities, dislocation of local communities from acquired areas, destruction of local livelihoods, and resources development that maximises marketable private benefits (e.g. mining) to the detriment of public benefits (e.g. access to clean water) (Anseeuw et al. 2012).

Finally, sustainable development is impeded, not just in relation to mining, by an incomplete accounting of sector impacts on comprehensive wealth (UNECA 2016). Figure 1 illustrates how economic wealth in comprehensive terms is composed of three broad categories of capital assets: infrastructure and financial capital, institutions and communities, and natural capital including biotic and abiotic components of the natural environment (see generally MEA 2005; World Bank 2011; Kumar 2012; Terama et al. 2016). A range of impacts on institutions and communities and biotic natural capital assets (including associated flows of ecosystem services) are not currently valued in markets and represent well-known externalities associated with the extractive sector.

When calculating the potential economic benefits of a mining project, both mining companies and governments tend to greatly exaggerate these by not taking into account environmental and social externalities. Hidden environmental and especially social costs of mineral extraction are typically underestimated or not estimated in monetary terms, even though these may greatly offset the real or perceived economic benefits of mining activities (Acosta 2013). Natural capital accounting, the importance of which has been recognised for African States in the 2012 Gaborone Declaration, can help make decision-makers aware of the environmental and resource impacts of mining, and help them estimate their quantitative importance.

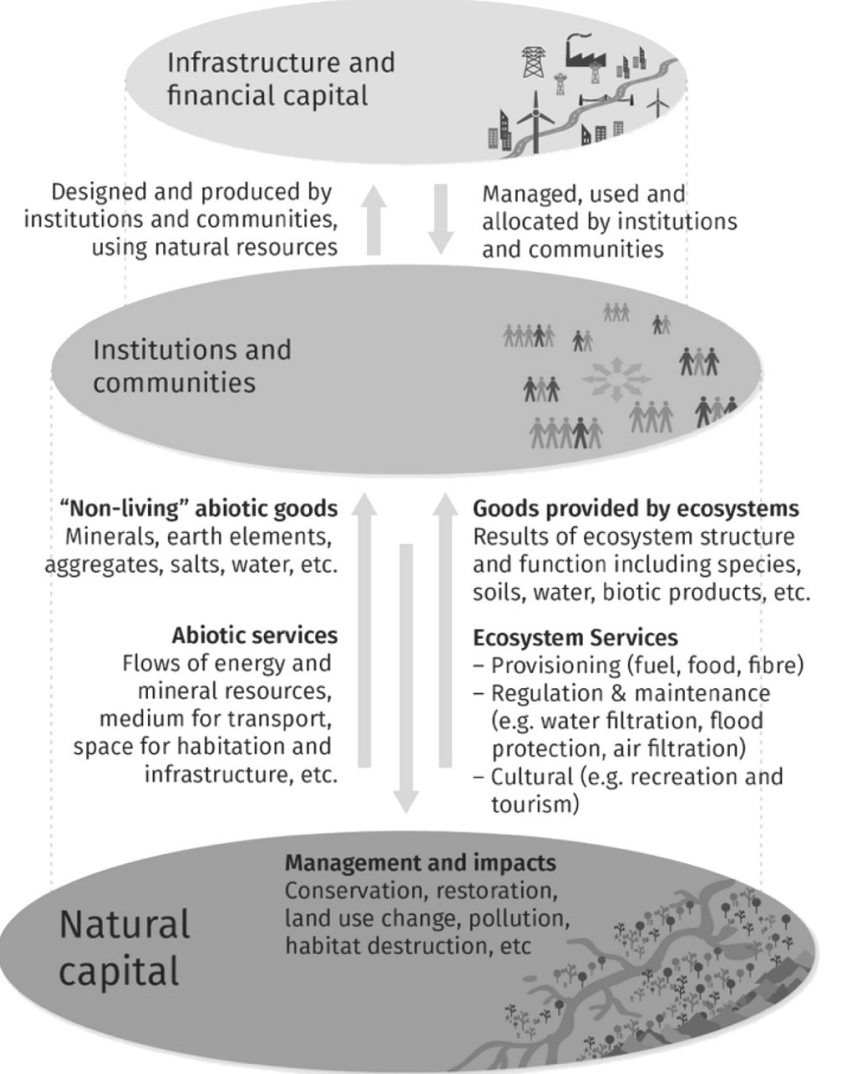

Fig. 1 Mineral resources in the context of comprehensive wealth

In addition, as all countries strive towards achieving sustainable development, it is not yet fully understood how to accelerate the decoupling of mineral resources use and environmental impacts from economic growth, nor how to minimise the negative impacts on developing countries of deep decarbonisation of global energy systems, and especially actions that will result in the stranding of fossil fuel deposits. There is a need to simultaneously achieve the different and not always aligned, imperatives of resource security and access, economic development and diversification in resource dependent developing countries, as well as the decoupling of natural resource extraction and related environmental degradation from economic progress.

\section{The sustainable development licence to operate}

Decision-making in the extractive sector is shaped by a complex global, regional, national and local architecture of relationships between individuals and institutions. The term governance refers to the many ways that individuals and institutions manage their common affairs in this context. Governance of the extractive sector is a process characterised by diverse actors, normative frameworks, hierarchical relationships, and spatial and temporal boundaries. These components are summarised below and illustrated in Fig. 2 below. 
In the following paragraphs, we provide a formative outline of the SDLO. It should be made clear at the outset that SDLO is not intended to function as a licence in the regulatory sense of that term. ${ }^{7}$ Instead it contains a flexible and coherent collection of principles and policy options, which over time will give rise to best practice that are practical in nature and applicable in diverse contexts at multiple spatial scales. As illustrated in Fig. 3, the SDLO is designed to function as a normative reference point for the multiple actors concerned with the extractive sector, enabling them to act in a coordinated and cooperative manner that supports the achievement of the 2030 Agenda for Sustainable Development. This involves building on the wider suite of relevant priorities, obligations and standards that are compatible with the SDGs, including but not limited to those relating to:

- National and regional economic development-including instruments such as the Africa Mining Vision, Gaborone Declaration for Sustainability in Africa.

- Environment and climate change-including Paris Agreement on Climate Change, Convention on Biological Diversity including the Aichi Biodiversity Targets, and United Nations Convention on the Law of the Sea.

- Human rights - including the UN Guiding Principles on Business and Human Rights.

- Trade and investment-including agreements of the World Trade Organisation.

- Industry best practice - examples of initiative setting standards for industry include the Global Reporting Initiative (GRI) and Extractive Industry Transparency Initiative (EITI).

Distilling practical principles and policy options from the complex of relevant norms is a significant undertaking, and only a preliminary and indicative attempt is made to do so here. It will become clear that there is no one-solution-fitsall, and that a flexible approach is required whereby proposed policy options and best practices account for and adapt to the specific socioeconomic, geopolitical, cultural and historical specificities of each particular area, country and region. However, the paragraphs that follow sketch out principles and policy options that are broadly applicable everywhere.

\footnotetext{
$\overline{7}$ Of note is that the choice of the word 'licence' in naming the new governance framework may misleadingly refer readers to the narrow notion of legal or other formal arrangements between host governments and mining companies. Yet, it should be clarified that this is but a single dimension of the much broader and encompassing mineral resource governance architecture envisioned and set forth in this paper. The wording of 'sustainable development licence to operate' is rather chosen to connect to and improve on the industry's aforementioned established approach of granting a 'social licence to operate' for engaging with stakeholders and improving development in the sector.
}

\section{Actors and stakeholder engagement in extractive sector governance}

The governance regime depicted in Fig. 2 operates as a holistic multi-level complex of formal and informal arrangements, encompassing governance institutions and mechanisms that act at the international, regional, national, local and project levels, and performed by a multitude of actors (Ekins and O'Keeffe 2014).

These actors include but are not limited to 'home' and 'host' governments, intergovernmental organisations, private commercial entities and 'third' sector actors such as non-governmental organisations, and diverse communities within civil society. Each of these actors pursues different sets of interests at different spatial and temporal scales, in different social, cultural, political, economic and environmental contexts. A characteristic feature of the extractive sector is the influential role played by transnational corporations (TNCs), ${ }^{8}$ including state-owned enterprises from other countries (Cotula 2013; Holden and Pagel 2013; UNCTAD 2009). The conflicting interests and asymmetries of information, negotiating skills, leverage and power between governments, TNCs and communities present important political economy challenges.

The divergence in expectations between stakeholders has been a key driver of conflict in the extractive industry. This happens as certain stakeholders may be excluded from the decision chain. Stakeholders may also lack knowledge of the economic specificities of a mining project, fail to collectively understand how mining can benefit each group and view value creation as a 'zero sum' game of winners and losers (Pedro 2015). A notable attempt by the World Economic Forum to address this is the Responsible Mineral Development Initiative, which entails a platform and tool to create a shared understanding of the benefits and costs of mining, and identify beneficial solutions (WEF 2017). ${ }^{9}$

Appropriate governance of mineral resources, so as to enhance their contribution towards sustainable development, is a shared responsibility along the mining value chain. From an ethical standpoint, developed importing nations should share responsibility for the adverse social and environmental impacts of mineral resource extraction occurring in mainly developing exporting countries. A global multi-level governance architecture will therefore need to address not only an agenda

\footnotetext{
${ }^{8}$ TNCs are composed of national entities located in more than one country, linked together by ownership or otherwise, under a coherent system of decision-making in which they can exercise significant influence over each other and share knowledge, resources and responsibilities (Sauvant 2015; Weissbrodt and Kruger 2003).

${ }^{9}$ The initiative adopts a broad view of the value from mineral development, identifying seven dimensions. These include the revenue streams (through tax, royalties, levies and fees), employment and skills acquisition, ensuring the respect for the environment and biodiversity, securing social cohesion and cultural gains, facilitating the entry of local entrepreneurs in the mining supply chain, promoting local beneficiation and downstream industry, and optimising mining infrastructure for development (Pedro 2015).
} 


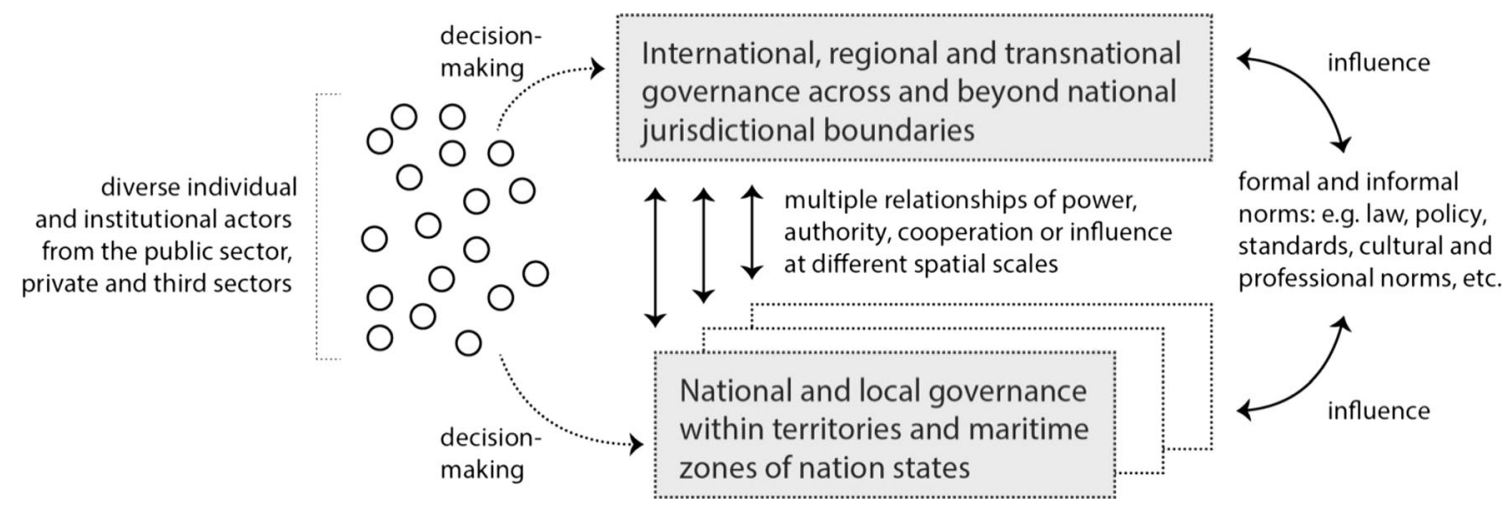

Fig. 2 Key components of extractive sector governance

for resource security, resource efficiency and decoupling of resource use and environmental impacts from economic growth that is of particular importance to developed nations but also the need for continuous economic development, structural transformation and economic diversification in resource exporting and other developing countries.

The SDLO envisages an inclusive multi-stakeholder approach, whereby decisions concerning the mining industry are made with the involvement of stakeholders. All relevant actors should be included through, among others, information exchange, media and other campaigns, and collaboration with institutions such as those with oversight roles. A communityorientated, context-sensitive approach to engagement requires in-depth knowledge of local culture, circumstances and power dynamics, alongside a sophisticated approach to engaging diverse voices (including alternative and marginalised voices) within affected communities (Owen and Kemp 2013). It is thereby important that industry engages in patient, long-term and broad-based collaborative social dialogue regarding each mining project, articulating an agenda which balances its own commercial needs with managing and meeting broader expectations about the contribution of mining to sustainable development (ibid).

\section{Comprehensive, consistent and flexible national governance regimes}

The SDLO can build on a plethora of existing policy options, initiatives and instruments. Nevertheless, there is a danger of 'initiative fatigue' as the 'proliferation of initiatives and lack of linkages make it challenging for mining companies to decide which ones to adopt and make a focus on sustainability more costly to implement' (Resolve and WEF 2015, p. 6). Importantly, for many countries, the challenge relates less to
Fig. 3 The Sustainable Development Licence to Operate (SDLO)

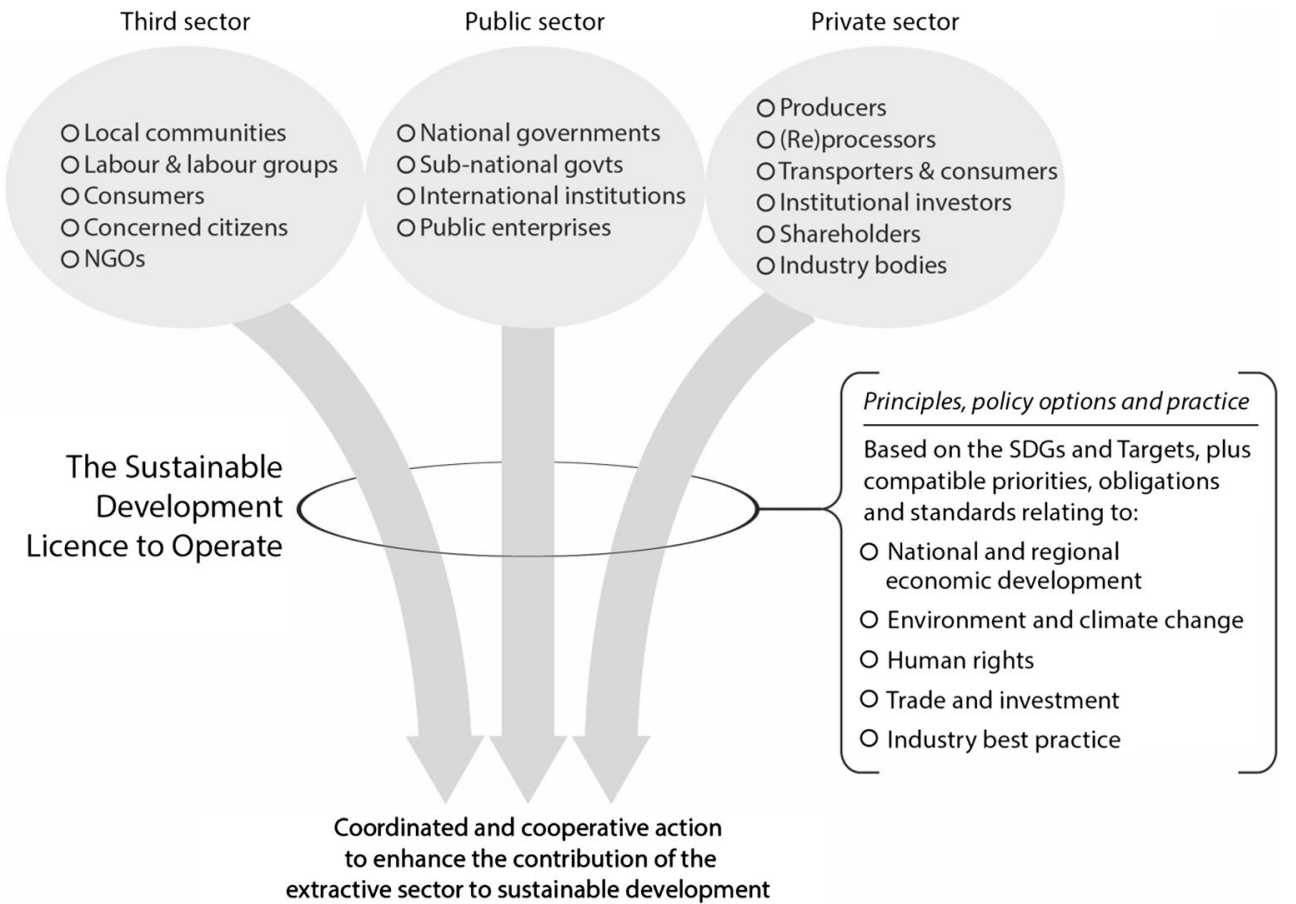


the absence of appropriate constitutional provisions, legislation, regulations, contracts and licences, but more to the challenge of enforcing these.

In addition, effective governance of the mining sector requires a legal system that is comprehensive, consistent and universally applicable to all projects. In addition to adopting policies/legislation, governments also need to build the institutional capacity to implement the rules. And rules and institutions, in turn, need to be supported by a critical mass of citizen understanding (Collier 2013). They also need to be appropriate to the local context. Differentiated governance approaches are needed, for instance, for countries where standards and guidelines can be easily implemented, compared to others with a large artisanal and small-scale mining sector, or with high levels of corruption, or that are affected by conflict and war. Governance strategies thus need to be tailored to a particular country's socioeconomic, geopolitical, historical and cultural background.

\section{Coherent global governance architecture}

Different actors and normative frameworks shape extractive sector governance at different spatial and temporal scales, including local, national, regional and international. The spatial boundaries of governance at each of these scales are often not aligned with the biophysical and spatial characteristics of resources, many of which are location-specific point resources. Mineral resources are concentrated in small areas and are unevenly distributed, which means that they must be exploited where they occur, most often through capital intensive techniques. Yet, many activities in the extractive sector, and impacts of these activities, straddle, migrate across or are affected biophysically by activity located beyond jurisdictional boundaries. A powerful recent example of such impacts is the collapse in November 2015 of a mine-tailing dam in Brazil, which generated a wave of toxic mud killing 20 people and severely affecting hundreds of kilometres of river, riparian lands and Atlantic coast across the two states of Minas Gerais and Espirito Santo (Couto Garcia et al. 2017).

The ubiquitous movement of extractive resources across national boundaries is driven by the organisation of production, trade and investment into globalised supply and value chains (Kaplinksky and Morris 2001; OECD et al. 2014). These chains have diverse characteristics - including different degrees of complexity, fragmentation, interconnectedness and resource intensity, and different structures of control and ownership (OECD 2013).

The management of mineral resources therefore requires interventions of different actors in different spatial horizons in both 'home' and 'host' countries. Setting clear legislative and political boundaries with regards to these strategic resources is important. Nigeria, for example, has legislated to include a minimum $13 \%$ derivation rule in its Constitution, for allocating oil and gas revenues to the nation's oil-producing states. Despite the introduction of such an instrument for the fairer distribution of extractive revenues between national and local governments, this has nevertheless led to unequal revenue transfers and failed to avert militant struggle in the Niger Delta (Iledar and Suberu 2010).

\section{Relevant normative frameworks}

Decision-making by different actors concerning the extractive sector is enabled, constrained and influenced by a wide variety of normative frameworks. More formal normative frameworks include treaties, constitutions, laws, policies, regulations, contractual agreements and technical standards. Less formal normative frameworks include administrative, commercial, professional, cultural and interpersonal practices.

The past two decades have also witnessed a plethora of domestic, regional and international legal and regulatory frameworks as well as formal and informal initiatives aimed at better governing the extractive industry for increased economic prosperity and environmental protection. These include many commendable examples such as the Africa Mining Vision, the UN Guiding Principles on Business and Human Rights, the Extractive Industry Transparency Initiative (EITI), the Dodd-Frank Act, the Global Reporting Initiative (GRI), the Model Mining Development Agreement, the Initiative for Responsible Mining Assurance, the Natural Resource Charter, the development of indicators to measure resource governance and the broader work of the International Council on Mining and Metals (ICMM).

In distinguishing between different normative frameworks, these include international agreements, national legislation and standards of practice.

International agreements establish a basic architecture of extractive sector governance at a global level, through the recognition of several general rights and obligations of nation states. For example, States are afforded permanent sovereignty over extractive resources within their respective territories, and sovereignty or sovereign rights over certain extractive resources depending on where they are located offshore.

National laws, policies and regulations establish detailed frameworks concerning rights to extractive resources, management and development of the extractive sector taking into account impacts on the environment and other economic sectors, and the allocation of associated benefits and impacts. An important issue in several countries is the discrepancy between formally recognised rights to resources, and the resource-related expectations and dependencies of local communities (Toulmin and Quan 2000).

Voluntary and private standards - As mining companies have sought to earn a 'social licence to operate', this has resulted in an explosion of soft regulation in recent years (Pedro 2015). Such voluntary initiatives are aimed at addressing potential 
consequences of mining on the environment (for instance, owing to tailing spills, deforestation, loss of biodiversity, soil erosion, water depletion and $\mathrm{CO}_{2}$ emissions), poverty and inequality, employment and inflation, immigration, displacement, loss of ancestral lands and livelihoods and other human rights violations.

Relationships - Both actors and normative frameworks are influenced and shaped by relationships of power, authority, cooperation or influence at multiple levels. These relationships can be hierarchical, or cooperative and voluntary. The prominent and influential role of private transnational entities, including TNCs, not-for-profit organisations and other formalised partnerships and associations, is a defining feature of extractive sector governance in recent decades. The ability of TNCs to influence extractivesector decision-making across globalised value chains depends on the governance structure of the chain in question. The aforementioned asymmetry of power between TNCs, government and communities, for instance, may prevent local communities from exercising their rights and developing country governments from securing a 'fair' mining deal. Different value chain structures afford different degrees of power and influence to TNCs. Figure 4 presents five well-known illustrative modes of interaction between different private sector actors within globalised value chains, and corresponding degrees of power asymmetry and coordination. Extractive sector value chains tend to be characterised by high levels of integration, with transnational mining companies exercising a high degree of coordination and power over private sector activities in the relevant value chain. A number of extractive sector TNCs participate in collaborative networks designed to promote better governance within and across global value chains - a focal point being the International Council for Mining and Metals.

While domestic laws and policies are critical in managing mining operations, rents and investment in host countries, there is also an important role to be played by home countries and the wider international community. A number of proposals have been put forward for improving the governance of resources (including mineral resources) at the global level in support of sustainable development. These range from the creation of extended sustainable commodity agreements to an International Convention on Sustainable Resource Management, an Integrated Resource Management Agency and an international metals covenant (Ekins and O'Keeffe 2014; Bleischwitz and Bringezu 2007; Bleischwitz et al. 2012; Wilts and Bleischwitz 2012). Proposals for such global governance regimes for sustainable resource management should complement other related arrangements in the mining sector and aim to promote mineral resource sufficiency and security of access, the decoupling of mineral resource use and impacts from economic growth, and the contribution of mineral resources to the achievement of the SDGs.

\section{Transparency and accountability}

A new governance approach must recognise that although appropriate legal, regulatory and voluntary frameworks and instruments may to a large extent already be in place to govern the mining sector, the problem is all too often the uneven or outright lack of their enforcement. In order to implement laws and policies governing the mining sector, transparency is an essential, even if not a sufficient, prerequisite.

Transparency is also important for helping to combat ills associated with transfer mispricing (whereby governments may lose out on tax revenues owing to the distorted prices applied to transactions within TNCs) and illicit financial flows (amounting to estimated annual losses of over 50 billion in Africa) (UNECA 2015).

The transformations that occurred in the marketplace due the financialisation of commodity markets are a cause of great debate. A key concern is the potential perverse impacts in commodity price formation, particularly those arising out of speculative practices which exacerbate price volatility and lead to price distortions (Cheng and Xiong 2014; Heumesser and Staritz 2013). In developing countries, this can lead to significant difficulties in managing macro-economic imbalances driven by volatile export revenues, changes in the balance of payments and public finances as well as in inflation and exchange rates.

The issue of transparency has received significant attention in international policy circles, and there have been some notable advances in this field, including the Extractive Industry Transparency Initiative (EITI), mandatory disclosure requirements in the European Union and the USA, as well as numerous national initiatives (Kaufman 2014). Several valuable diagnostic tools have also been developed, including the Resource Governance Index. ${ }^{10}$ Yet, analysis using this tool shows that fewer than $20 \%$ of resource relevant countries displayed adequate quality of transparency and accountability (Revenue Watch Institute 2013) (see Fig. 5).

Further inroads have to be made to increase transparency in a number of areas across the value chain, including mining contracts and licences, social and environmental impact assessments, royalties and tax payments at the project level, as well as state-owned enterprises, sovereign wealth funds and beneficial ownership of mining companies (Kaufman 2014). In this endeavour, responsibility does not only rest with governments and industry but also with countless other nongovernmental actors, who include unions, non-governmental organisations, think thanks and academics, and who can share public auditors' burden, analysing data, reporting on findings, and demanding more accountable governance and management in the mining sector (ibid).

\footnotetext{
10 The Resource Governance Index (RGI) has been developed by the Revenue Watch Institute and assesses the quality of four key governance components: institutional and legal setting, reporting practices, safeguards and quality controls, and enabling environment. It further includes information on stateowned companies, natural resource funds and subnational revenue transfers (Revenue Watch Institute 2013).
} 


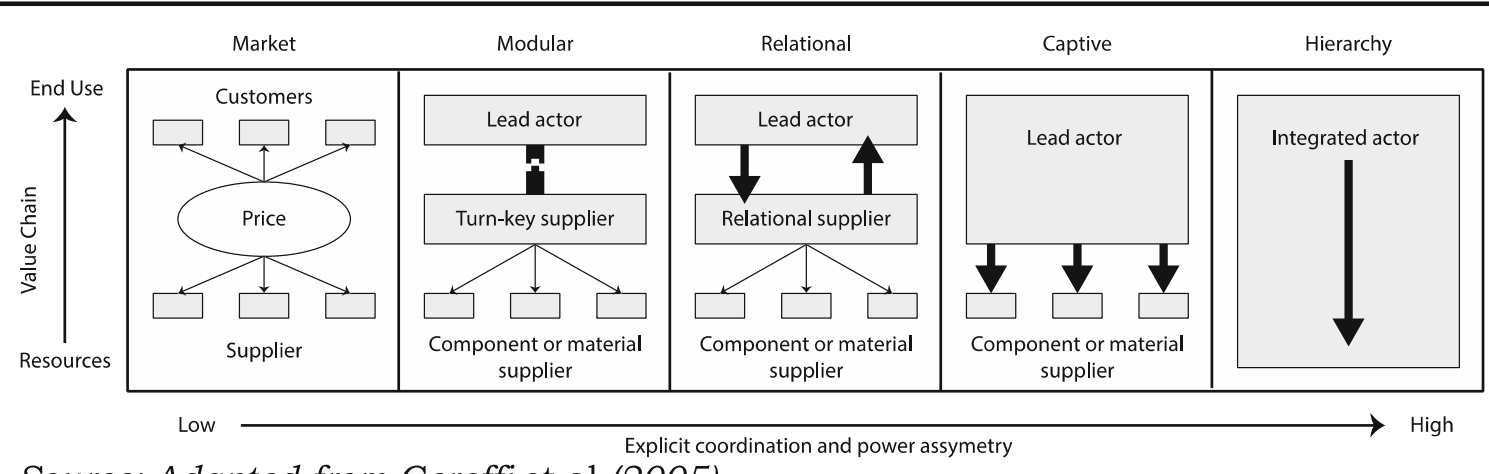

Source: Adapted from Gereffi et al (2005)

Fig. 4 Interaction between private sector actors within global value chains. Source: adapted from Gereffi et al. (2005)

While greater transparency is critical for ensuring accountability and hence successful policy implementation, it also has to be accompanied by efforts to fight corruption, improve the rule of law, and protect civil and political rights (including press freedom) (Kaufman 2014). These are important prerequisites for effective governance of the mining sector to ensure companies commit to the highest environmental, social and human rights standards, and the sector contributes towards sustainable development.

\section{Support for broad development objectives, including poverty reduction, economic diversification and structural transformation}

In establishing a new governance framework for the mining sector, it is essential to understand the sector within the broader context of a national economy, and its development objectives and strategies. This means both managing the potential impacts of mineral resource extraction on other parts of the economy (such as on the artisanal and small-scale mining sector), as well as maximising linkages between the mining sector and other parts of the economy (including through job creation, local procurement of goods and services, the downstream use of mined goods, and shared infrastructure). This will require a long-term comprehensive strategy, going beyond industry regulation to also include investment in education and training, and other policies for creating an enabling environment.

In the case of low-income resource-rich countries, governance strategies need to focus on breaking away from the enclave nature and extractivistmodel of the mining sector. Countries need to build forward and backward linkages with other socioeconomic sectors, build infrastructure and capacity for greater value addition along the value chain, and promote regional partnerships and integration. A range of structural reforms and industrial policies need to be implemented to help achieve structural transformation and economic diversification. Developed countries and the global community need to afford developing countries sufficient policy space to do so, including through reform of the international trade and investment regime that constrains the use of the full range of policy instruments to achieve resource-based industrialisation at the local level (Acosta 2013; UNECA and African Union 2011).

The Africa Mining Vision (AMV) presents one such comprehensive governance framework that extends beyond the narrow confines of the mining sector, to also advocate for linkages to

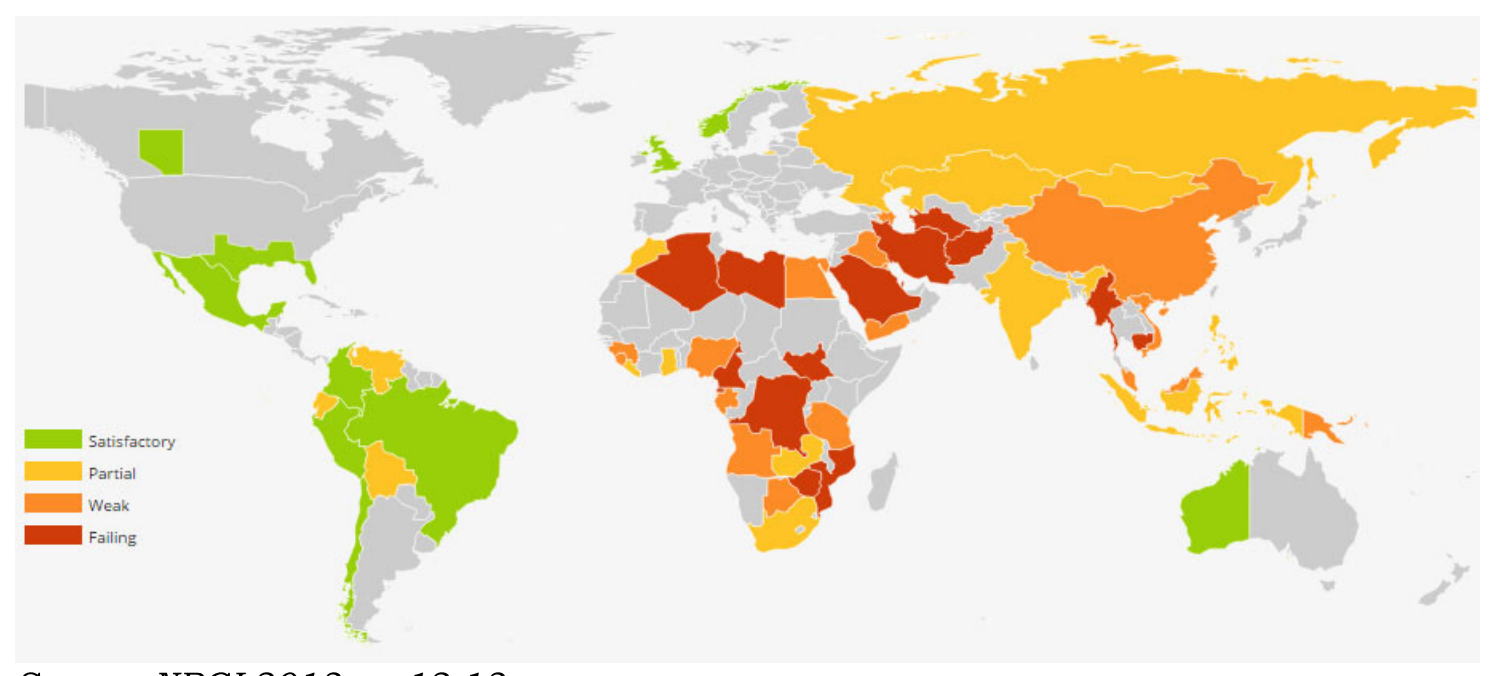

Source: NRGI 2013, p. 12-13

Fig. 5 Mapping the governance deficit. Source: NRGI 2013, pp. 12-13 
other sectors, diversification, development of socioeconomic infrastructure and regional integration. The AMV Action Plan, which is structured around programme clusters, specific goals, outcomes and activities, was developed in 2011 for the practical application of the vision for the continent. The AMVAction Plan, which is structured around programme clusters, specific goals, outcomes and activities, was developed in 2011 for the practical application of the vision for the continent (Pedro 2016).

A result-oriented monitoring framework has also been developed to assess AMV compliance, as measured by the level of implementation of the 83 activities recommended by the AMV Action Plan (GIZ2014). Approaches such as the AMV could be replicated in other regions and implemented at the national level. Another example of a suggested comprehensive approach to governance of the extractive sector is the Natural Resource Charter, which is a set of 12 precepts that put forward choices and strategies in order to increase the sustainable development benefits of natural resource exploitation. An accompanying Benchmark Framework has also been developed as a tool for the management of oil, gas and minerals against global best practice as prescribed in the Charter (NRGI 2016).

\section{Systems thinking}

In addition to examining the inter-linkages between the mining sector and other socioeconomic sectors, there is also a need to look at the dynamic relationships between minerals and other natural resources such as land, energy and water. Extractive industries place large demands on these resources, risk polluting water resources and can lead to biodiversity loss and ecosystem destruction. This calls for a systems-thinking approach that accounts for the nexus between resources so as to steer policy efforts towards integrated natural resource management along the mining value chain.

In this context, strategic environmental impact assessments and integrated spatial planning or landscape planning are crucial to ensure that a mining project effectively contributes to local and national development. These instruments help protect local habitats, manage forests and water resources more sustainably, arbitrate between conflicting land use options and reduce poverty and improve the livelihoods of local communities.

\section{Inclusiveness and reduced gender and other inequalities}

An important element of the SDLO is recognition that mining activities can impact men and women in a different manner. Special attention should be paid to the role of women in artisanal and small-scale mining, their growing portion of employment in large-scale mining, and the adverse environmental and social impacts of mining that can disproportionately affect women. Examples of the latter include the impact of deforestation on women's ability to collect water and fuel, or the rise of prostitution to serve mine workers and associated risks of sexually transmitted diseases including HIV/AIDS. A gender lens therefore needs to be adopted in governing the mining sector in order to maximise its development contribution, whilst also promoting female empowerment and gender equality that are central to the achievement of the SDGs.

A similar need for differentiated analysis and policies may also arise with respect to other groups, such as indigenous people, who may be marginalised.

\section{Potential policy instruments}

The principles outlined above would need to be operationalised through a range of policies along the entire mining value chain (that is, from licencing of mineral terrains, geological mapping, mineral exploration, mine development, mining, mineral processing and refining, ore transportation, manufacturing of enduse products, to recycling and mine closure). Van der Lugt (2014), based on Gunningham and Grabosky (1998), summarises examples of policy and regulatory instruments that can be applied in an appropriate mix of mandatory and voluntary instruments, creating both carrot and stick incentives, to advance the environmental performance of the sector.

On command and control regulation, possible instruments include environmental standards (e.g. process standards, technology standards, performance standards), permits and licences (e.g. point source or facility), and covenants (negotiated agreements, co-regulation). Economic and market-based instruments vary and include property rights, market creation, fiscal instruments (e.g. taxes, charges, subsidies), financial instruments, liability instruments, performance bonds, deposit refund systems (solid waste), removing perverse subsidies and sustainable procurement. On self-regulation (industry group or social control), there are standards and codes of practice. Voluntarism can also be practiced at the individual firm level or in the context of corporate social responsibility. Education, capacity building and information instruments include education and training, corporate environmental reporting, community right to know and pollution inventories, product verification and labelling, and award schemes (Van der Lugt 2014, based on Gunningham and Grabosky 1998).

There is a strong case for governing the extractive industries through detailed robust laws and regulations, rather than reliance on the negotiation of extensive and complex individual mining contracts as is often the case in developing countries. Contracts should as far as possible be consistent with the general legislative framework, include standardised terms, avoid stabilisation clauses, be allocated through a competitive bidding process and be accessible in the public domain. ${ }^{11}$ This

\footnotetext{
${ }^{11}$ The Mining Law Committee of the International Bar Association has developed a comprehensive and common template to aid developing countries negotiate and agree a mining contract that supports the contribution of the project towards sustainable development (see www.mmdaproject.org).
} 
Fig. 6 Value chain for extractive industries. Source: World Bank (2009). http://siteresources. worldbank.org/INTOGMC/ Resources/ei_for_development 3.pdf

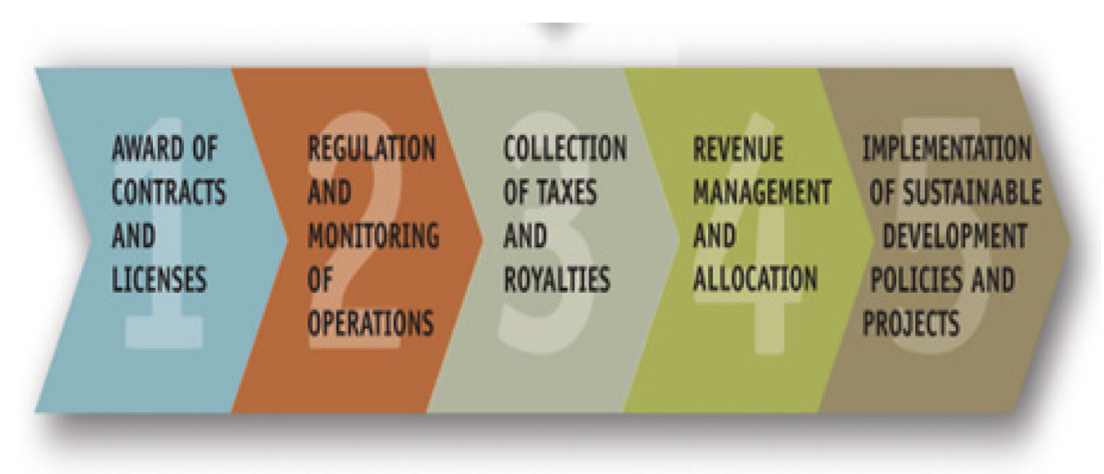

Source: World Bank (2009) can help the government maintain a coherent strategy for the sector and broader economy, reduce the challenges associated with the negotiation of each project (particularly amid asymmetries in negotiating skills and leverage), facilitate effective rule enforcement by easing the work burden of regulatory and oversight bodies, and increase transparency and accountability (UNSDSN 2015).

Support for broad development objectives is likely to require a coherent formulation and coordinated implementation of a wide range of policies, which may relate to such issues as local content, shared infrastructure, international trade, investment, industrial policy, education and training, and many others, and which can help strengthen institutions, build capacities and create an enabling environment.

At the global level, policy action is needed for setting global standards in the form of rules and regulations, voluntary initiatives and reporting obligations in areas that include:

- coordination of mining policies and initiatives and agreement on international mining standards [including pressurising transnational corporations (TNCs) to disclose information and adhere to global codes of conduct, and ensuring host countries receive a fair deal];

- influencing incentives and behaviour (examples of policies being extended consumer responsibility and ecolabelling of metals);

- technology transfer; and

- regulation of the financialisation of commodities, and to curtail illicit financial transactions, transfer-pricing abuse, use of tax havens and other tax evasion or avoidance techniques.

The World Bank has developed a value chain approach for the extractive industries aimed at supporting countries translate mineral and hydrocarbon wealth into sustainable development, shown in Fig. $6 .^{12}$

\footnotetext{
12 This framework was popularised by Collier (2007), with several institutions such as the Revenue Watch Institute, the World Bank, the Natural Resource Governance Institute and the Extractive Industries Transparency Initiative (EITI) having since developed similar value chain approaches for the extractive sector.
}

Policies need to be designed at each of the illustrated different stages of the extractive sector value chain, which for space limitation are not described further. The implementation of the various policy options identified will differ from country to country depending on the local context, but some policies will very likely be required at each of the identified stages of the value chain.

\section{Upward harmonisation of best practices}

A number of authors have recognised the need to achieve the upward harmonisation of global standards of good practice for the mining sector to contribute to sustainable development (see, for example, Nickless et al. 2015). What is required is a set of international guidelines for what is acceptable, for instance, in terms of environmental, social and human rights impacts of mineral extraction, getting a fair deal and share of profits, profit repatriation, transparency and accountability, and investing in the future and in support of sustainable development objectives, along the lines discussed above. The guidelines would need to be used to set clear and concrete benchmarks for countries and companies to aim for. A formal mandate could be given to an institution such as the International Organisation for Standardisation to develop such global standards and benchmarks of good practice, which will need to include new reporting guidelines (for example those of the Global Reporting Initiative - GRI), and sustainability indicators (such as the Responsible Mining Index being developed by the Responsible Mining Foundation).

\section{Concluding remarks}

The paper argues that despite the many challenges and complexities of managing extractive resources, there are also tremendous opportunities from using mineral resource wealth to spearhead sustainable and inclusive development. Examples of countries such as Botswana today, and the Nordic countries and the USA in the last century provide evidence that resource riches can act as positive drivers (and not a 'curse') for the required structural transformation towards sustainable development. But what these country examples also highlight is the importance of governance 
for achieving positive economic, social and environmental outcomes. Governments need to put in place clear, comprehensive and transparent laws, policies and regulations, build strong institutions, train skilled professionals and set up accountability mechanisms to ensure that policy frameworks and rules are implemented. At the same time, the challenges associated with rising resource nationalism, policy revisionism (including from denials of climate change), volatile commodity prices and threats to multi-lateralism would need to be overcome. This will require close collaboration and cooperation between countries and actors, with all relevant stakeholders incorporating the principles enshrined in the SDGs into their own practices and operations.

This new governance paradigm has here been called a 'sustainable development licence to operate', as a development of the 'social licence to operate' paradigm, to reflect the significant potential contribution of the mining sector to realise the sustainable development of mineral-rich developing countries. The new paradigm extends over multiple dimensions (local, national, regional and global) and calls for the reconciliation of the aspirations of the different actors (including multi-national companies, governments, non-governmental organisations, civil society organisations and land users) in the extractive sector to ensure shared benefits from mining. The underlying principles and policy options outlined above, which form the basis of the proposed framework, should serve as useful benchmarks for its operationalisation.

Open Access This article is distributed under the terms of the Creative Commons Attribution 4.0 International License (http:// creativecommons.org/licenses/by/4.0/), which permits use, duplication, adaptation, distribution and reproduction in any medium or format, as long as you give appropriate credit to the original author(s) and the source, provide a link to the Creative Commons license and indicate if changes were made.

\section{References}

Acosta A (2013) Extractivism and neoextractivism: two sides of the same curse. In: Lang M, Mokrani D (eds) Beyond development: alternative visions from Latin America, vol 6. Rosa Luxemburg Foundation and Amsterdam: Transnational Institute, Quito, pp 1$86 \mathrm{https}: / /$ www.tni.org/files/download/beyonddevelopment extractivism.pdf

African Union (2009) Africa mining vision. http://www. africaminingvision.org/amv_resources/AMV/Africa_Mining Vision_English.pdf

Agrawal A, Gibson CC (1999) Enchantment and disenchantment: the role of community in natural resource conservation. World Dev 27:629-649

Anseeuw W, Alden Wily L, Cotula L, Taylor M (2012) Land rights and the rush for land: findings of the global commercial pressures on land research project. International Land Coalition, Rome

Bleischwitz R, Bringezu S (2007) Global resource management: conflict potential and characteristics of a global governance regime. Stiftung Entwicklung und Frieden, Bonn

Bleischwitz R, Bahn-Walkowiak B, Ekardt F, Feldt H, Fuhr L (2012) International resource politics-new challenges demanding new governance approaches for a green economy. Publication Series on ecology volume 26. Heinrich Böll Foundation, Berlin

Business Council of British Columbia (2015) Rethinking social licence to operate - a concept in search of definition and boundaries. Environ Energy Bull 7(2)

CCSI et al. (2016) Mining a mirage? Reassessing the shared-value paradigm in light of the technological advances in the mining sector. http://ccsi.columbia.edu/work/projects/the-mine-of-the-future/

Cheng I, Xiong W (2014) Financialisation of commodity markets. https:// www.princeton.edu/ w wxiong/papers/Review_Financialization.pdf

Collier P (2007) The bottom billion: why the poorest countries are failing and what can be done about it. Oxford University Press, Oxford http://www.sfu.ca/content/sfu/dean-gradstudies/events/ dreamcolloquium/SpringColloquium/Readings/Readings/_jcr content/main_content/download_47/file.res/Paul\%20Collier

Collier P (2013) Under pressure: good management of a resource discovery needs informed citizens and informed government. Finance and Development

Cotula L (2013) The great african land grab? Agricultural investments and the global food system. Zed Books, London and New York

Cotula L, Vermeulen S, Leonard R, Keeley J (2009) Land grab or development opportunity? Agricultural investment and international land deals in Africa. FAO, International Institute for Environment and Development, International Fund for Agricultural Development

Cotula L, Oya C, Codjoe EA, Eid A, Kakraba-Ampeh M, Keeley JLaokaley A, Kidewa M, Makwarimba W, Seide M, Nasha WO, Asare RO, Rizzo M (2014) Testing claims about large land deals in Africa: findings from a multi-country study. J Dev Stud 50(7):903-925

Couto Garcia L, Ribeiro DB, de Oliveira Roque F, Ochoa-Quintero JM, Laurance WF (2017) Brazil's worst mining disaster: corporations must be compelled to pay the actual environmental costs. Ecol Appl 27(1):5-9

Ekins P, O'Keeffe M (2014) Concept note for a possible IRP report on governance of the extractive industry. A proposal from Paul Ekins and Michelle O'Keeffe, UCL Institute for Sustainable Resources, University College London, for discussion at the IRP Rotterdam Meeting in November 2014

EY (2015) Business risks facing mining and metals 2015-2016. http:// www.ey.com/gl/en/industries/mining—metals/business-risks-inmining-and-metals

Gereffi G, Humphrey J, Sturgeon T (2005) The governance of global value chains. Rev Int Polit Econ 12(1):78-104

GIZ (2014) A gap analysis of African mining vision implementation in Liberia and Sierra Leone. German Federal Ministry for Economic Cooperation and Development

Gunningham N, Grabosky P (1998) Smart regulation: designing environmental policy. Clarendon Oxford University Press, Oxford

Heumesser C, Staritz C (2013) Financialisation and the microstructure of commodity markets - a qualitative investigation of trading strategies of financial investors and commercial traders. http://www. oefse.at/fileadmin/content/Downloads/Publikationen/ Workingpaper/WP44_financialisation.pdf

Holden J, Pagel M (2013) Transnational land acquisitions: what are the drivers, levels, and destinations of recent transnational land acquisitions? EPS-PEAKS Consortium

ICMM (2016) Role of mining in national economies. Mining contribution index, third edition supplement. ICMM, London

Iledar W, Suberu R (2010) Oil and gas resources in the Federal Republic of Nigeria. Framework paper. World Bank Conference on Oil and Gas in Federal Systems. March 3-4, 2010

Joyce S, Thomson I (2000) Earning a social licence to operate: social responsibility and resource development in Latin America, CIM Bulletin, 49-53

Kaplinksky R, Morris M (2001) A handbook for value chain research. International Development Research Centre, Ottawa 
Kaufman D (2014) Evidence-based reflections on natural resource governance and corruption in Africa, Africa at a fork in the road: taking off or disappointment once again, The Yale Center for the Study of Globalization. April, 2014

Kumar P (2012) The economics of ecosystems and biodiversity: ecological and economic foundations. Routledge Press, Oxford

Lesser P, Suopajärvi L, Koivurora T (2017) Challenges that mining companies face in gaining and maintaining a social license to operate in Finnish Lapland. Miner Econ 30:41-51

MEA (2005) Millennium ecosystem assessment, ecosystems and human well-being: synthesis. Island Press, Washington, DC

Nickless E, Ali S, Arndt N, Brown G, Demetriades A, Durrheim R, Enriquez M A, Giurco D, Kinnaird J, Littleboy A, Masotti F, Meinert L, Nyanganyura D, Oberhänsli R, Salem J, Schneider G, Yakovleva N (2015) Resourcing future generations: a global effort to meet the world's future needs head-on. International Union of Geological Sciences. http://iugs.org/uploads/RFG\%20Report-sm.pdf

NRGI (2013) The 2013 resource governance index: a measure of transparency and accountability in the oil, gas and mining sector. A report by the Natural Resource Governance Institute. http://www. resourcegovernance.org/resource-governance-index http://www. resourcegovernance.org/sites/default/files/rgi_2013_Eng.pdf

NRGI (2016) Natural resource charter benchmarking framework. Natural Resource Governance Institute. http://www.resourcegovernance. org/sites/default/files/documents/precept-combined.pdf

OECD (2013) Interconnected economies: benefiting from global value chains: synthesis report

OECD, WTO and World Bank (2014) Global value chains: challenges, opportunities, and implications for policy

Owen JR, Kemp D (2013) Social licence and mining: a critical perspective. Resour Policy 38:29-35

Palmer D, Arial A, Metzner R, Willmann R, Muller E, Kafeero F, Crowley E (2012) Improving the governance of tenure of land, fisheries and forests. FAO Land Tenure Journal 1

Pedro A (2015) Towards a sustainable development licence to operate: the resource governance imperatives. Concept note for the development of a report by the International Resource Panel on Governance of the Extractive Industry, presented for discussion at the UN EnvironmentInternational Resource Panel Expert Workshop on Resource Governance held on 15-16 October 2015 in Davos, Switzerland

Pedro A (2016) The country mining vision: towards a new deal. Miner Econ 29(1):15-22

Prno J (2013) An analysis of factors leading to the establishment of a social licence to operate in the mining industry. Resour Policy 38: 577-590 http://www.sciencedirect.com/science/article/pii/ S0301420713000810

PWC (2015) Mine 2015, the gloves are off: review of global trends in the mining industry. http:/www.pwc.com/gx/en/mining/publications/ assets/pwc-e-and-m-mining-report.pdf

Resolve and WEF (2015) Voluntary responsible mining initiatives: a review. White paper. By RESOLVE Solutions Network and World Economic Form. August, 2015

Revenue Watch Institute (2013) The 2013 Resource Governance Index: a measure of transparency and accountability in the oil, gas and mining sector
Rights and Resources Initiative (RRI) (2016) Closing the gap: strategies and scale needed to secure rights and save forests. Rights and resources initiative annual review 2015-2016

Sauvant KP (2015) The negotiations of the United Nations code of conduct on transnational corporations: experience and lessons learned. J World Invest Trade 16:11-87

Stevens P, Lahn G, Kooroshy J (2015) The resource curse revisited. Chatham House Research Paper

Suárez SM, Osorio LM, Langford M (2009) Voluntary guidelines for good governance in land and natural resource tenure: civil society perspectives, FAO Land Tenure Working Paper 8

Terama E, Milligan B, Jimenez-Aybar R, Mace GM, Ekins P (2016) Accounting for the environment as an economic asset: global progress and realizing the 2030 agenda for sustainable development. Sustain Sci 11(6):945-950

Toulmin C, Quan J (2000) Evolving land rights, policy and tenure in Africa. IIED, DFID

UNECA (2015) Track it! Stop it! Get it! Illicit Financial Flows. Report of the High Level Panel on Illicit Financial Flows from Africa. Commissioned by the AU/ECA Conference of Ministers of Finance, Planning and Economic Development

UNECA (2016) Africa's blue economy: a policy handbook. http://www. uneca.org/sites/default/files/PublicationFiles/blue-eco-policyhandbook_eng_1nov.pdf

UNECA and African Union (2011) Minerals and Africa's Development: The International Study Group Report on Africa's Mineral Regimes. United Nations Economic Commission for Africa

United Nations Conference on Trade and Development (2009) World Investment Report 2009: Transnational Corporations, Agricultural Production, and Development. UNCTAD/WIR/2009

UNSDSN (2015) Harnessing natural resources for sustainable development: challenges and solutions. http://unsdsn.org/wp-content/ uploads/2014/02/TG10-Final-Report.pdf

Van der Lugt C T (2014) Global resource governance and poverty: scoping paper on a new work steam of the international resource panel

Weissbrodt D, Kruger M (2003) Norms on the responsibilities of transnational corporations and other business enterprises with regard to human rights. Am J Int Law 97(4):901-922

Wilts H, Bleischwitz R (2012) Combating material leakage: a proposal for an international metal covenant. Sapiens 4(2):1-9

World Bank (2009) Extractive industries value chain: a comprehensive integrated approach to developing extractive industries. Eleodoro Mayorga Alba. Extractive Industries for Development Series \#3. Africa Region Working Paper Series \#125

World Bank (2011) The changing wealth of nations: measuring sustainable development for the new millennium. The World Bank, Washington, D.C.

World Economic Forum (2016) Toward transparency and best practices for deep seabed mining: an initial multi-stakeholder dialogue. http:// www3.weforum.org/docs/WEF_Toward_Transparency_Best_ Practices_Deep_Seabed_Mining_2016.pdf

World Economic Forum (2017) Mining and metals industry visions 2017. Davos-Klosters, Switzerland 17-20 January 